\title{
Seasonal occurrence and role of protistan parasites in coastal marine zooplankton
}

\author{
Alf Skovgaard ${ }^{1,2, *}$, Enric Saiz $^{1}$ \\ ${ }^{1}$ Institut de Ciències del Mar, Departament de Biologia Marina i Oceanografia, CSIC, Passeig Marítim de la Barceloneta 37-49, \\ 08003 Barcelona, Catalonia, Spain
}

${ }^{2}$ Present address: University of Copenhagen, Department of Phycology, Øster Farimagsgade 2D, 1353 Copenhagen K, Denmark

\begin{abstract}
The prevalence of parasites and epibionts associated with zooplankton in coastal waters of the NW Mediterranean Sea was studied through fortnightly sampling from July 2003 to January 2005. The most commonly found parasites were dinoflagellates of the genera Syndinium and Blastodinium infecting a range of planktonic copepod species, for the most part females. The lethal parasite S. turbo was found in the calanoid copepod Paracalanus parvus all year round, but primarily during summer and autumn. Up to $7 \%$ of female $P$. parvus were visibly infected with $S$. turbo, corresponding to an estimated parasite-induced mortality rate of up to $0.15 \mathrm{~d}^{-1}$. The parasitic castrators Blastodinium spp. were generally found only from summer to late autumn. The most common Blastodinium species was B. mangini parasitizing the cyclopoid copepod Oncaea cf. scottodicarloi with up to $17 \%$ of females visibly infected. This corresponded to an estimated impairment of the reproductive rate of $0.16 \mathrm{~d}^{-1}$. The epibiotic diatom Sceptronema orientale infested on average $34 \%$ of adults of the harpacticoid copepod Euterpina acutifrons from late summer until early winter, but was absent during spring and early summer. Occurrence of the dinoflagellate Oodinium sp., a parasite of appendicularians, was seasonally very restricted with a peak of $14 \%$ of Oikopleura sp. infected in late summer. Other parasites such as Paradinium spp., Ellobiopsis spp. and the epibiotic diatom Pseudohimantidium pacificum were found more sporadically on various copepod species. The results indicate that parasitism in marine zooplankton is a common phenomenon that has the potential to play an important role in the population dynamics of marine zooplankton.
\end{abstract}

KEY WORDS: Zooplankton $\cdot$ Copepod $\cdot$ Parasite $\cdot$ Mortality $\cdot$ Sterility

\section{INTRODUCTION}

Parasitism is a common phenomenon in both terrestrial and aquatic ecosystems, and parasites are recognized as potential regulating factors for their host populations in line with, for example, predators (Andersen \& May 1978). A host is typically harmed by its parasite, but sometimes this may not be evident and, therefore, the distinction between parasitism and non-harmful associations like commensalism or mutualism is not always easy (Cameron 1956). The existence of parasitism is well documented in marine zooplankton (Ho \& Perkins 1985), but knowledge on the effect of parasites on zooplankton populations is limited. A considerable amount of research has been devoted to the taxonomy of parasites of marine zooplankton organisms (Chatton 1920, Sewell 1951, Théodoridès 1989), but the prevalence of parasites, their ecological relevance and their influence on energy transfer in pelagic ecosystems remain poorly resolved.

The most frequent parasites in marine zooplankton appear to be protists, and most of these are hosted by copepods (Chatton 1920); however, appendicularians, chaetognates, radiolarians and various groups of gelatinous zooplankton organisms are also parasitized (Théodoridès 1989). Several parasites of marine cope- 
pods, such as the genera Blastodinium and Syndinium, are dinoflagellates (Chatton 1920, Fensome et al. 1993), but also protistan parasites of other taxonomic groups infect marine zooplankton. Among these, Paradinium spp. were previously considered to be related to the dinoflagellates (Chatton 1920), but their taxonomic affiliations are uncertain (Cachon et al. 1968, Chatton \& Soyer 1973). Another genus, Ellobiopsis, is likewise of uncertain taxonomic affiliation, but evidence points toward ellobiopsids belonging to the alveolates (Silberman et al. 2004), i.e. the line of protists comprised of ciliates, apicomplexans, dinoflagellates and relatives. Some diatoms and ciliates thrive as epibionts on the exoskeletons of freshwater zooplankton (Green 1974, Fernandez-Leborans \& Tato-Porto 2000), and this phenomenon is also found in marine copepods (Hiromi et al. 1985, Carman \& Dobbs 1997, Ohtsuka et al. 2004).

The effect of parasitism on the individual zooplankton host varies with parasite species. Some species, such as ellobiopsids, induce sterility in the infected females (Wickstead 1963, Albaina \& Irigoien 2006). The same applies to the dinoflagellate genus Blastodinium (Chatton 1920, Sewel 1951, Skovgaard 2005) that, in addition, lowers the fitness of the host (Skovgaard 2005) and may cause copepodites to fail to moult to the adult stage (Chatton 1920). Syndinium spp. comprise an example of lethal parasites that literally devour their host (Chatton 1920). Epibiotic algae and ciliates have less severe effects on their hosts but may cause physiological stress and increased susceptibility to grazers (Xu \& Burns 1991, Allen et al. 1993). However, attached ciliates can have various life styles. While most species are passive epibionts or exuviotrophs (Bradbury 1996), others become histophageous when their host is injured or ingested by a predator (Grimes \& Bradbury 1992).

Parasitism is historically overlooked as a regulating factor in marine zooplankton. However, a few case studies have shown that parasitic dinoflagellates can cause mortality and reduce fecundity in copepod populations (Wickstead 1963, Kimmerer \& MacKinnon 1990). The topic has been more intensively studied in freshwater zooplankton, and several studies have shown that parasitism can regulate Daphnia magna populations under laboratory conditions (Ebert et al. 2000). Further studies are needed, however, before one can state conclusively that this is also the case for natural marine populations (Ebert 2005, available at: www.ncbi.nlm.nih.gov/entrez/query.fcgi? db=Books). It is not obvious from the literature whether the small importance attributed to parasitism in marine zooplankton is due to a general low prevalence of parasites or because the subject is understudied. The present work aimed to shed light on the possible im- portance of parasitism in marine zooplankton by focusing on the occurrence of parasites and epibionts in NW Mediterranean mesozooplankton. The aim was to include all protistan parasites that could be detected through routine microscopy with special care taken to optimize visual detection of the parasites.

\section{MATERIALS AND METHODS}

Sampling. Fortnightly sampling was carried out from July 2003 to January 2005 in the NW Mediterranean Sea at a fixed station (38 $\mathrm{m}$ depth) half a nautical mile off Port Olímpic, Barcelona, Spain $\left(41.22^{\circ} 775^{\prime} \mathrm{N}\right.$, $02.13^{\circ} 150^{\prime} \mathrm{E}$ ). Five additional samples were collected in spring 2003. Zooplankton was collected with a $100 \mu \mathrm{m}$ mesh size plankton net hauled vertically from the bottom to the surface. Live (qualitative) samples were collected with a plastic bag mounted on the plankton net and were kept in seawater-filled thermo boxes until arrival at the laboratory where they were manipulated at ambient seawater temperature. Parallel (quantitative) samples collected with a net provided with a screened cod end were fixed immediately on board with borax-buffed formaldehyde $(4 \%$ final concentration). All samples were transferred to the laboratory within $1 \mathrm{~h}$ of sampling and fixed samples were stored immediately at $4{ }^{\circ} \mathrm{C}$ in darkness until processing. This storage method has been used to enhance preservation of chlorophyll in photosynthetic parasites (Skovgaard 2005).

Quantitative measures of parasite and epibiont prevalence. For determination of total abundances of zooplankton in the preserved samples, at least 300 (300 to 900) animals were counted, corresponding to 0.5 to $30 \%$ of the total sample volume. Both uninfected and infected individuals were counted in these sample fractions. Some numerically dominant species (Paracalanus parvus, Oncaea cf. scottodicarloi and Euterpina acutifrons) were often found to be infected. To achieve more accurate estimates of infection prevalence for these species in samples where they were less abundant, larger additional sample fractions (10 to $80 \%$ of total sample) were processed. Uninfected and infected individuals of these most frequently parasitized species, as well as infected individuals of all other species, were counted in these larger sample fractions.

Qualitative and semi-quantitative measures of occurrence of parasites and epibionts. Parasites were often more visible in live animals. For this reason, on each sampling date 2 live samples were examined qualitatively for the presence of zooplankton organisms infected with parasites or carrying epibionts. This was done by concentrating the samples, dividing them into smaller portions and inspecting each of these 
subsamples for the presence of live, infected animals, using a stereomicroscope. Dark-field illumination usually facilitated the recognition of endoparasites. In case of doubt, apparently infected hosts were dissected in order to confirm the presence of endoparasites or they were incubated for 24 to $48 \mathrm{~h}$ in $3 \mathrm{ml}$ of $0.2 \mu \mathrm{m}$ filtered seawater in order to see if possible endoparasites (of the genera Syndinium, Blastodinium and Paradinium) would become more conspicuous and/or develop spores. In addition, semi-quantitative measures of parasite prevalence were established as (0) no infected hosts observed in the 2 live samples, (1) 1 infected host observed, (2) 2 to 3 infected hosts observed, (3) $>3$ infected hosts observed.

Identification and photographic documentation. Photographs of live copepods and parasites were made using a Canon PowerShot G2 digital camera mounted on an Olympus stereomicroscope or on a Nikon Diaphot microscope. Principal literature used for the identification of parasites was from Chatton (1920) and Sewell (1951) for dinoflagellates, Cachon et al. (1968) for Paradinium spp., Caullery (1910) and Hovasse (1951) for Ellobiopsis spp., and Gibson (1979) and Takano (1983) for diatom epibionts.

\section{RESULTS}

\section{Total mesozooplankton abundance}

Copepods were the overall numerically dominant zooplankton organisms with highest general abundances from summer until early winter (Fig. 1). Other common zooplankton organisms comprised appendicularians, cladocerans, doliolids, chaetognates, pteropods and heliozoans. Most abundant of these organisms were the appendicularian Oikopleura sp. and the cladoceran Penilia avirostris, but together these 2 organisms constituted at most one-third of total zooplankton numbers. Parasites and epibionts were found only in copepods and in Oikopleura sp. Microzooplankton was not examined.

\section{Blastodinium spp.}

Several species of the plastidic dinoflagellate genus Blastodinium were found in the gut of various copepod species, usually only in juvenile or adult females (Fig. 2). The largest and most conspicuous of these parasites, B. contortum, occurred as a solitary trophont, a growing and feeding parasitic stage, in the calanoid copepods Paracalanus parvus, Clausocalanus spp. and Nanocalanus minor (Fig. 2A,B). Found only sporadically in the latter 2 host organisms (Table 1), B. contor-

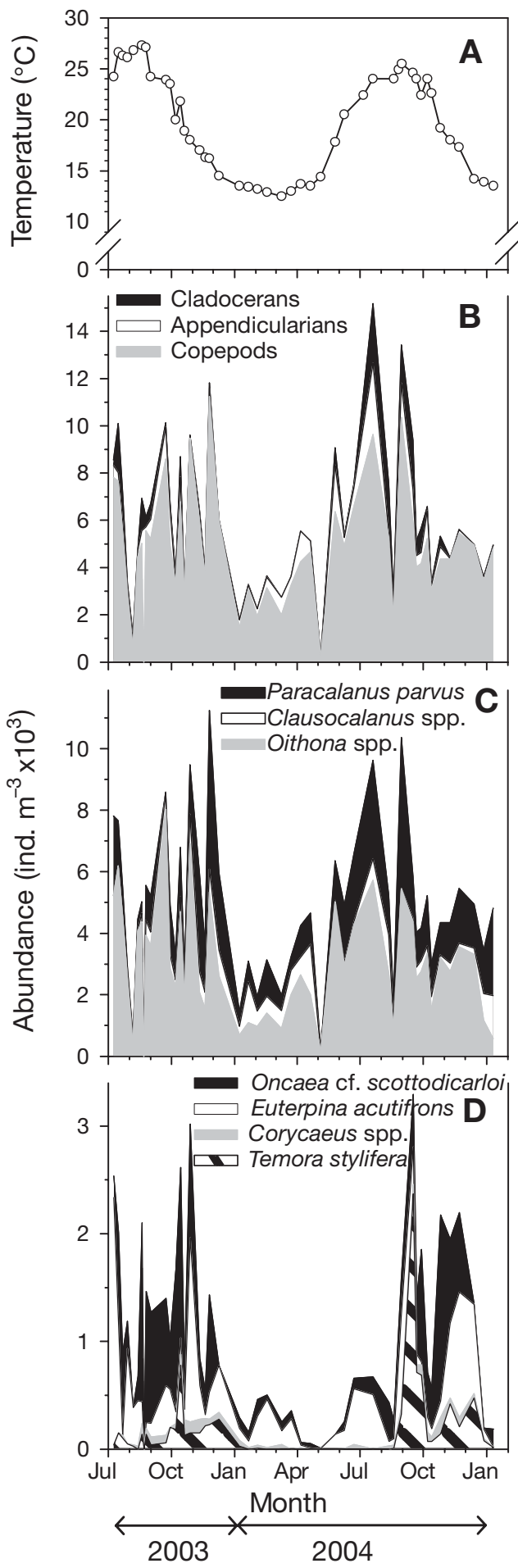

Fig. 1. (A) Surface seawater temperature at a fixed station in the NW Mediterranean Sea during the sampling period. (B) Total mesozooplankton abundance (less common groups such as chaetognates, doliolids, heliozoans and pteropods were too numerically rare to be shown). (C) Total abundance of most common copepod species. (D) Total abundance of less common copepod species (rarer genera such as Candacia, Calocalanus, Euchaeta, Microsetella, Nanocalanus, and Oncaea species other than $O$. cf. scottodicarloi are not shown) 


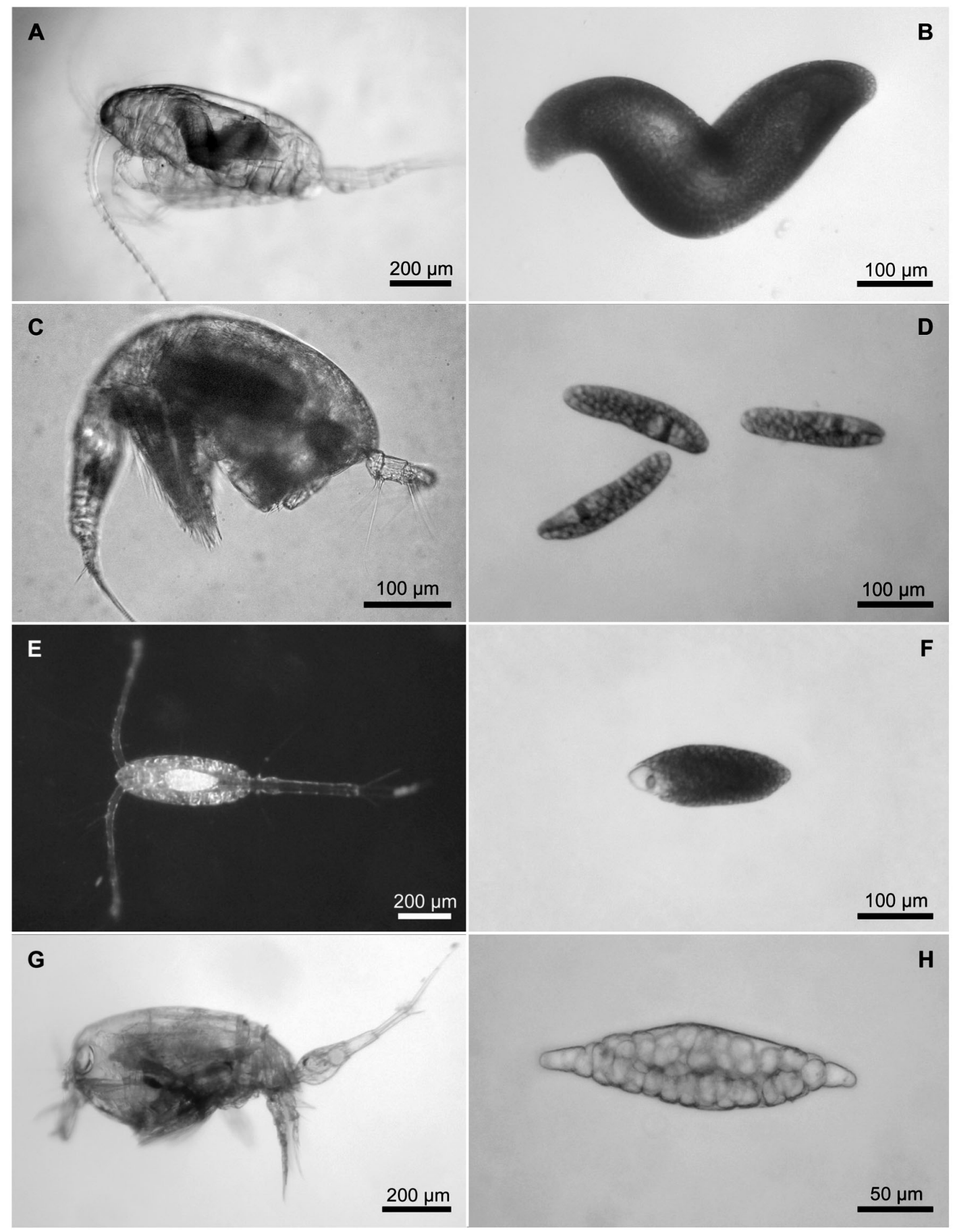

Fig. 2. (A) Clausocalanus arcuicornis female infected with Blastodinium contortum. (B) B. contortum trophont isolated from the host in (A). (C) Oncaea cf. scottodicarloi female containing several B. mangini trophonts. (D) Three single B. mangini trophonts isolated from an $O$. cf. scottodicarloi female. (E) Oithona similis female with B. oviforme. (F) B. oviforme trophont from an O. similis female. (G) Corycaeus giesbrechti female containing several B. navicula trophonts. $(\mathrm{H}) \mathrm{B}$. navicula trophont isolated from a $C$. giesbrechti female

tum was more common in $P$. parvus, even though infection prevalence in females never exceeded $5 \%$ (Table 1, Fig. 3C). Occurrence of B. contortum showed a clear seasonal scheme with most copepods infected during autumn, whereas the parasite was absent from the plankton in spring and early summer (Table 1, Fig. 3B,C).

Blastodinium mangini was the most common species of this genus, infecting the cyclopoid (poecilostomatoid) copepod Oncaea cf. scottodicarloi (Fig. 2C,D). 
Table 1. Parasitic protists in NW Mediterranean zooplankton in the period April 2003 to January 2005. x: parasite observed in this month; s: parasite observed and semi-quantitative data available (Figs.3, 4 \& 6); q: parasite observed and quantitative and semiquantitative data available (Figs. 3, 4 \& 6)

\begin{tabular}{|c|c|c|c|c|c|c|c|c|c|c|c|c|c|}
\hline \multirow[t]{2}{*}{ Parasite/epibiont } & \multirow[t]{2}{*}{ Host } & \multicolumn{12}{|c|}{ Month of observation: } \\
\hline & & Jan & Feb & Mar & Apr & May & Jun & Jul & Aug & Sep & Oct & Nov & Dec \\
\hline Blastodinium contortum & Clausocalanus arcuicornis & & & & & & & & & & $\mathrm{x}$ & $\mathrm{x}$ & \\
\hline Blastodinium contortum & Clausocalanus sp. & $\mathrm{x}$ & & & & & & $\mathrm{x}$ & & $\mathrm{x}$ & $\mathrm{x}$ & $\mathrm{x}$ & $\mathrm{x}$ \\
\hline Blastodinium contortum & Nanocalanus minor & & & & & & & & & & $\mathrm{x}$ & & \\
\hline Blastodinium contortum & Paracalanus parvus & q & q & & & & & q & & q & q & q & q \\
\hline Blastodinium hyalinum & Paracalanus parvus & & $\mathrm{x}$ & $\mathrm{x}$ & & & & & & & $\mathrm{x}$ & $\mathrm{x}$ & $\mathrm{x}$ \\
\hline Blastodinium mangini & Oncaea cf. scottodicarloi & q & & & & & q & q & q & q & q & q & q \\
\hline Blastodinium navicula & Corycaeus giesbrechti & & & & & & & & $\mathrm{q}$ & $\mathrm{q}$ & q & & $\mathrm{q}$ \\
\hline Blastodinium oviforme & Oithona plumifera & & & & $\mathrm{x}$ & & & $\mathrm{x}$ & & & & & \\
\hline Blastodinium oviforme & Oithona similis & & $\mathrm{s}$ & & $\mathrm{s}$ & & & $\mathrm{s}$ & & $\mathrm{s}$ & $\mathrm{s}$ & & \\
\hline Blastodinium pruvoti & Clausocalanus arcuicornis & & & & & & & & & & & $\mathrm{x}$ & \\
\hline Blastodinium spinulosum & Clausocalanus arcuicornis & $\mathrm{x}$ & & & & & & & & & $\mathrm{x}$ & & $\mathrm{x}$ \\
\hline Blastodinium sp. & Farranula sp. & & & & & & & & & & $\mathrm{x}$ & & \\
\hline Blastodinium sp. & Clausocalanus sp. & & & & & & & & & & $\mathrm{x}$ & & \\
\hline Syndinium turbo & Paracalanus parvus & q & q & & q & q & & q & q & q & q & q & q \\
\hline Syndinium sp. & Clausocalanus arcuicornis & & & & & & & & & & $\mathrm{x}$ & & \\
\hline Syndinium sp. & Corycaeus giesbrechti & & & & & & & & & & & $\mathrm{x}$ & \\
\hline Syndinium sp. & Corycaeus sp. & & & & & & & & & & $\mathrm{x}$ & & \\
\hline Syndinium sp. & Euterpina acutifrons ${ }^{\mathrm{a}}$ & & & & & & & & $\mathrm{x}$ & & $\mathrm{x}$ & $\mathrm{x}$ & $\mathrm{x}$ \\
\hline Syndinium sp. & Oithona similis & & & & & & & & & & & & $\mathrm{x}$ \\
\hline Oodinium sp. & Oikopleura sp. & & & & & & & q & q & q & q & & \\
\hline Ellobiopsis fagei. & Calocalanus sp. & $\mathrm{x}$ & & & & & & & & & $\mathrm{x}$ & $\mathrm{x}$ & \\
\hline Ellobiopsis sp. & Temora stylifera $^{\mathrm{a}}$ & & & & & & & & & & $\mathrm{x}$ & & \\
\hline Paradinium poucheti & Oithona similis & & & $\mathrm{s}$ & $\mathrm{s}$ & & $\mathrm{s}$ & & $\mathrm{s}$ & & & & \\
\hline Paradinium sp. & Euterpina acutifrons $^{\mathrm{a}}$ & & & $\mathrm{x}$ & & & & & & & $\mathrm{x}$ & & \\
\hline Ciliate & Corycaeus giesbrechti & & & & & & & & $\mathrm{x}$ & $\mathrm{x}$ & $\mathrm{x}$ & $\mathrm{x}$ & \\
\hline Pseudohimantidium pacificum & Corycaeus spp. & & $\mathrm{s}$ & $\mathrm{s}$ & & & & $\mathrm{s}$ & & $\mathrm{s}$ & $\mathrm{s}$ & s & $\mathrm{s}$ \\
\hline Sceptronema orientale & Euterpina acutifrons & q & & q & & & & q & q & q & q & q & q \\
\hline
\end{tabular}

Usually each infected host contained 3 to 5 parasite trophonts. This species was present from June to January, but was completely absent from February to April (Table 1, Fig. 3G,H). Highest prevalence was $17 \%$ of females infected and infection frequencies of $>10 \%$ was not uncommon for $O$. cf. scottodicarloi females (Fig. 3H). Unlike other Blastodinium spp. hosts, adult and juvenile males of $O$. cf. scottodicarloi were also infected (data not shown), but highest prevalence was found among females. For both $B$. contortum and $B$. mangini, highest infection frequencies coincided with the seasons when their hosts were most abundant in the plankton (Fig. 3).

Blastodinium oviforme (Fig. 2E,F) infected females of the cyclopoid copepods Oithona spp. at low prevalence at various time of the year (Table 1, Fig. 4C,D). There was always only 1 parasite trophont in each host. Oithona similis was the host most frequently infected, but several B. oviforme-infected specimens of Oithona plumifera were also observed (Table 1). Except from late autumn and winter, Oithona spp. were typically among the most abundant organisms in the zooplank- ton, but only relatively low percentages of Oithona spp. were visibly parasitized (Fig. 4D). About half of the Oithona spp. adults in the quantitative samples were $O$. nana, which was never infected. The actual infection frequencies of $O$. similis and $O$. plumifera are, therefore, underestimates, because Oithona species were not separated quantitatively.

Blastodinium navicula (Fig. 2G,H) occurred in the cyclopoid (poecilostomatoid) copepod Corycaeus giesbrechti from August to December (Fig. 4F). Like $B$. mangini, this parasite was gregarious and up to 8 trophonts were contained in each infected host. Due to the natural opaqueness of C. giesbrechti, its endoparasites were barely visible without the dissection of the host. The seasonality of $B$. navicula resembled that of $B$. mangini, but $B$. navicula occurred in a more restricted time period (Table 1, Fig. 4F). C. giesbrechti always occurred in low total numbers and was not present in all samples. Other less frequent Blastodinium species included B. pruvoti and B. spinulosum, which both parasitized Clausocalanus spp. Both species were, however, only observed in a few samples in late 


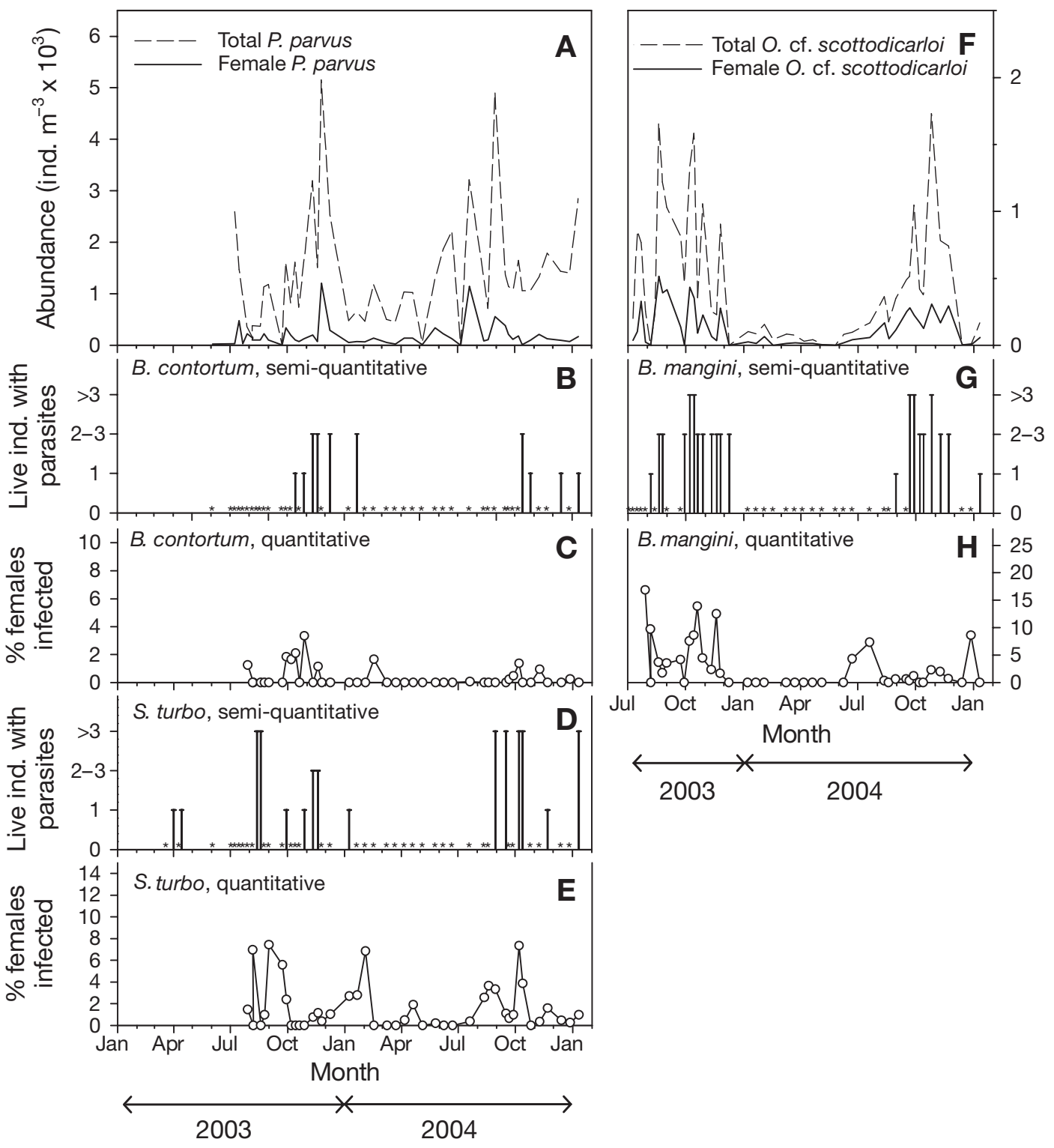

Fig. 3. (A) Paracalanus parvus. Total abundance and female abundance (total abundance may include early stage copepodites of similar species). (B) Semi-quantitative prevalence of Blastodinium contortum-infected P. parvus females (bars). (C) Quantitative prevalence of B. contortum in P. parvus females. (D) Semi-quantitative prevalence of Syndinium turbo-infected $P$. parvus females (bars). (E) Quantitative prevalence of $S$. turbo in P. parvus females. (F) Oncaea cf. scottodicarloi: total abundance and abundance of females. (G) Semi-quantitative prevalence of $O$. cf. scottodicarloi females infected with B. mangini (bars). (H) Quantitative prevalence of $B$. mangini in $O$. cf. scottodicarloi females. $(\mathrm{B}, \mathrm{D}, \mathrm{G}){ }^{*}$ : sample in which the parasite was not observed

autumn and winter (Table 1). The non-pigmented species B. hyalinum was present in a few Paracalanus parvus from October through March (Table 1).

\section{Syndinium spp.}

Syndinium turbo parasitized Paracalanus parvus during most of the year with highest prevalence typi- cally in late summer and autumn (Table 1, Fig. 3D,E). In late stages of infection, the infected hosts could be recognized by a swelling of the prosome and a dark discoloration caused by the endoparasite plasmodium (Fig. 5A). Up to $7 \%$ of $P$. parvus females were visibly infected with $S$. turbo on several occasions and an infection prevalence of 3 to $5 \%$ was common all year, but spring tended to be the season with lowest percentages of infected animals (Fig. 3D,E). Syndinium 


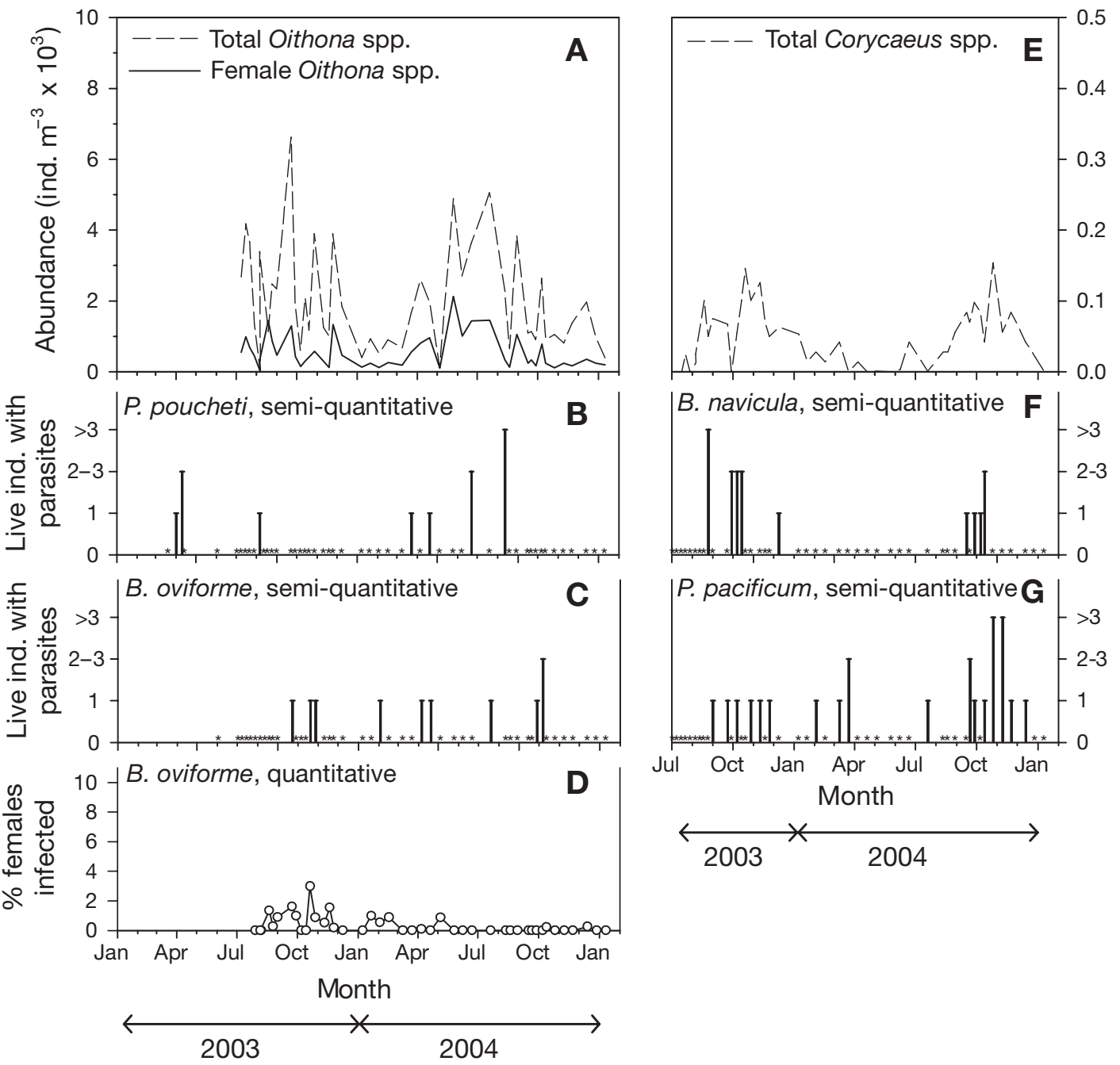

Fig. 4. (A) Oithona spp. total abundance and abundance of females. (B) Semi-quantitative prevalence of $O$. similis females infected with Paradinium poucheti (bars). (C) Semi-quantitative prevalence of Oithona spp. females infected with Blastodinium oviforme (bars). (D) Quantitative prevalence of B. oviforme in Oithona spp. females. (E) Total abundance of Corycaeus spp. (F) Semi-quantitative prevalence of C. giesbrechti infected with B. navicula (bars). (G) Semi-quantitative prevalence of Corycaeus spp. carrying the diatom epibiont Pseudohimantidium pacificum (bars). (B,C,F,G) *: sample in which the parasite was not observed

spp. were also occasionally found in Clausocalanus arcuicornis, Corycaeus giesbrechti, Corycaeus sp. and in Oithona similis (Table 1). Finally, Syndinium sp. was found to infect the harpacticoid copepod Euterpina acutifrons (Fig. 5B), which has not previously been reported as a host for this parasite. After its detection for the first time in August 2004, Syndinium sp. infections of $E$. acutifrons were repeatedly observed during the rest of this survey. It is likely that it was systematically overlooked at the beginning of the survey, since the only feature revealing a Syndinium sp. infection in E. acutifrons was a slightly increased opacity of the host. Neither in live nor in fixed material did the parasite notably alter the size or shape of the host.

\section{Paradinium spp.}

Females of the cyclopoid copepod Oithona similis were found to be infected by the parasite Paradinium poucheti (Fig. 5C). As it is inconspicuous, it was not possible to detect this endoparasite internally in its host, implying that it was recognizable only when external sporangia had been formed. The sporangia were attached to the caudal rami of the host's urosome. They were probably lost during fixation of the zooplankton, since Paradinium spp. sporangia were found only in live material. Therefore, no quantitative measures of parasite abundance were obtained. Semiquantitative data, however, suggested that occurrence of $P$. poucheti was restricted to spring and summer 

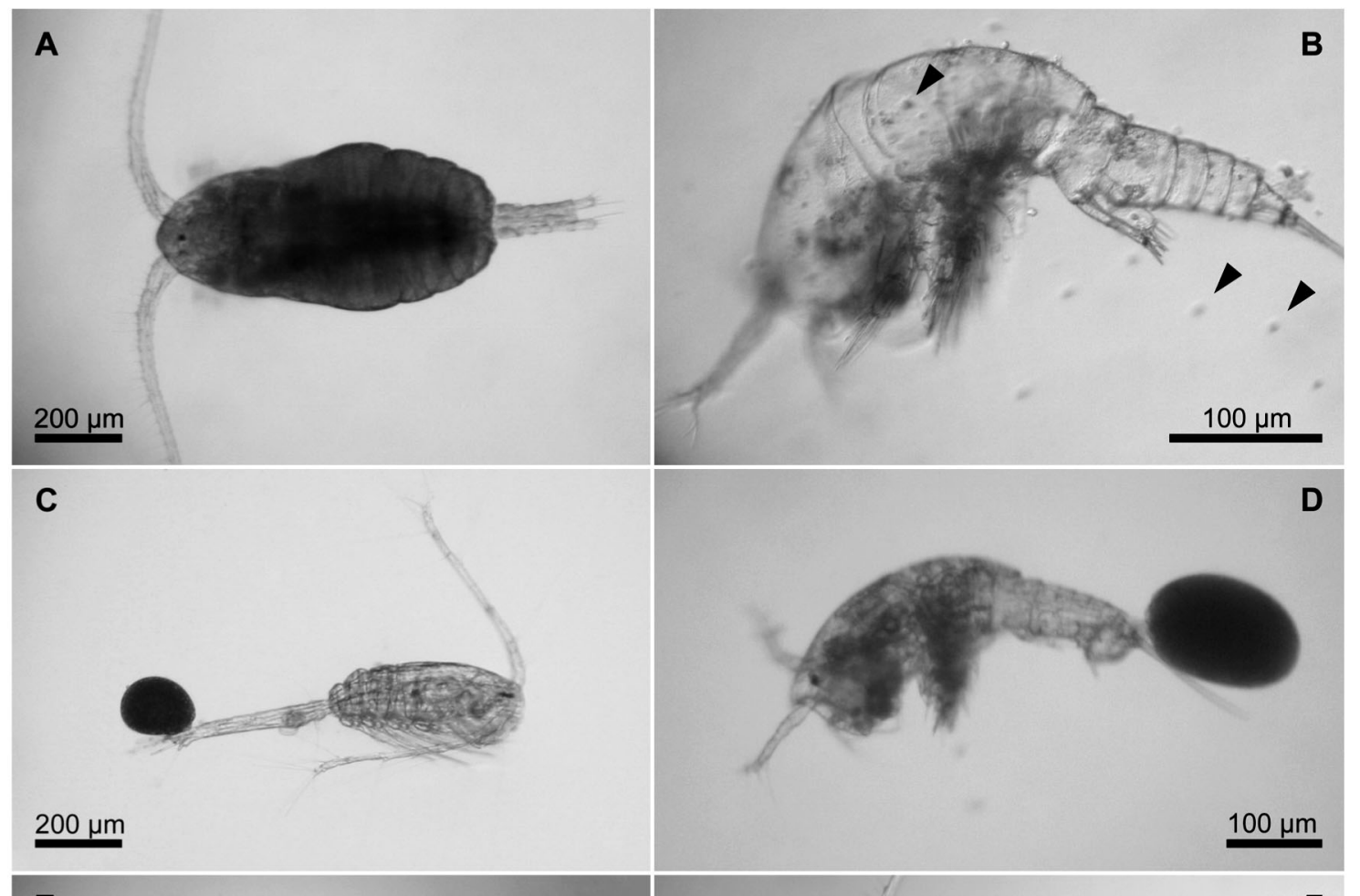

$200 \mu \mathrm{m}$

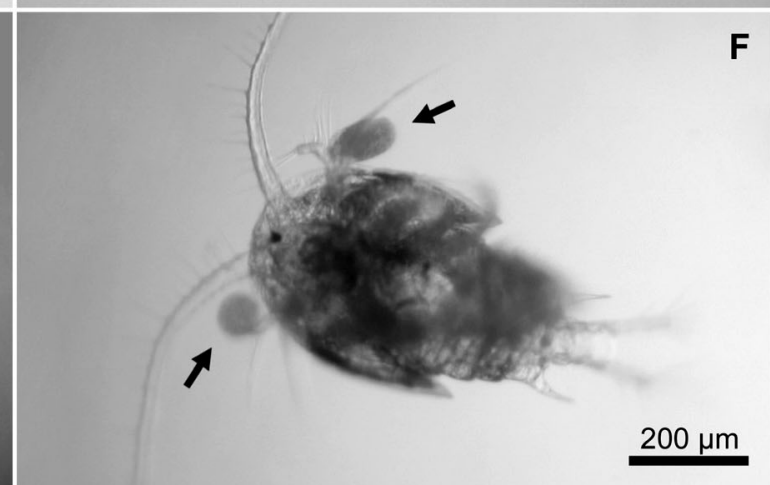

G
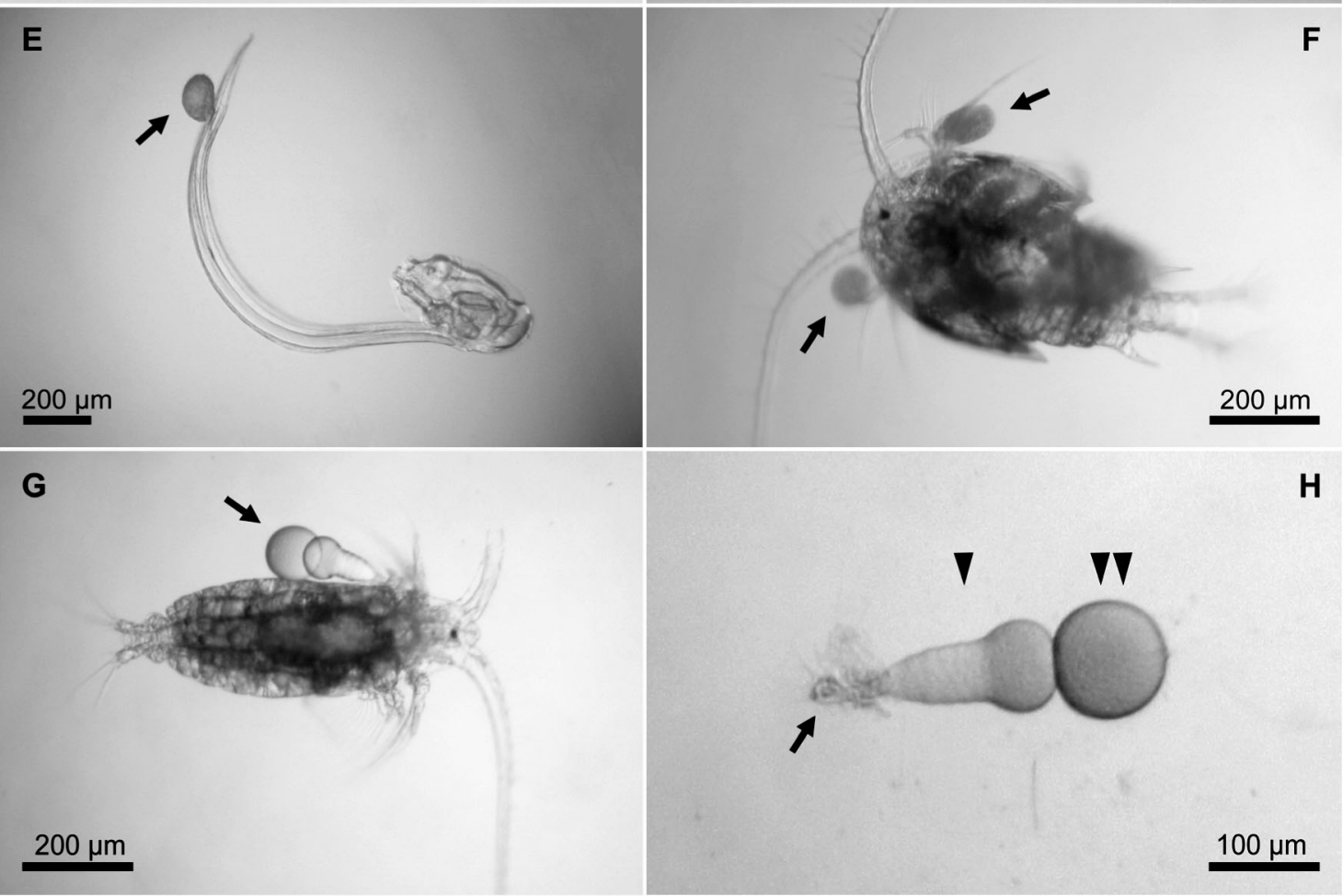

Fig. 5. (A) Syndinium turbo in live Paracalanus parvus female, parasite plasmodium is visible as dark mass inside the swollen prosome of the host. (B) Euterpina acutifrons exoskeleton from a host that has been infected and devoured by Syndinium sp., a few Syndinium sp. cells (arrowheads) are visible inside and around the empty exoskeleton. (C) Paradinium poucheti sporangium attached to the urosome of an Oithona similis female. (D) Paradinium sp. sporangium attached to the urosome of E. acutifrons. (E) Oodinium sp. (arrow) attached to the tail of Oikopleura dioica. (F) Two young Ellobiopsis sp. (arrows) attached to Temora stylifera copepodite. (G) Ellobiopsis fagei (arrow) attached to Calocalanus sp. copepodite. (H) E. fagei trophont from (G) showing the stalk (arrow), trophomere (arrowhead), and gonomere (double arrowhead) 
(Table 1, Fig. 4B). Two specimens of Euterpina acutifrons were also found to be infected by Paradinium sp. (Table 1, Fig. 5D). For both species, their hosts remained viable after the production of Paradinium spp. sporangia, but their further survival was not followed.

\section{Oodinium sp.}

Appendicularians of the genus Oikopleura were infected with the dinoflagellate parasite Oodinium sp. (Fig. 5E) in July to September 2003, and in August to October 2004 (Table 1, Fig. 6B,C). During the rest of the year, Oodinium sp. was completely absent even though Oikopleura sp. were present and common almost the whole year round except in winter (Fig. 6B,C). Highest prevalence of Oodinium sp. was in late August 2003 when $14 \%$ of all Oikopleura sp. were infected with 1 or more parasites. This coincided with an unusually high surface seawater temperature of $27.3^{\circ} \mathrm{C}$.

\section{Ellobiopsis spp.}

From October through January, a few copepodites of the calanoid copepods Calocalanus sp. and Temora stylifera were found carrying ellobiopsid parasites attached to their antennules and feeding appendages (Fig. 5F-H). Based on size and morphology, the species infecting Calocalanus sp. was identified as Ellobiopsis fagei. Prevalence of ellobiopsids on Calocalanus sp. and $T$. stylifera was not determined because only 5 to 6 infected individuals of each species were found.

\section{Epibionts}

The diatom Sceptronema orientale (Fig. 7A,B) was found on up to $68 \%$ of Euterpina acutifrons adults with an average of $34 \%$ infested adults from August to December, 2003, and from September to October 2004 (Fig. 6E,F). On average $14 \%$ of juveniles were infested
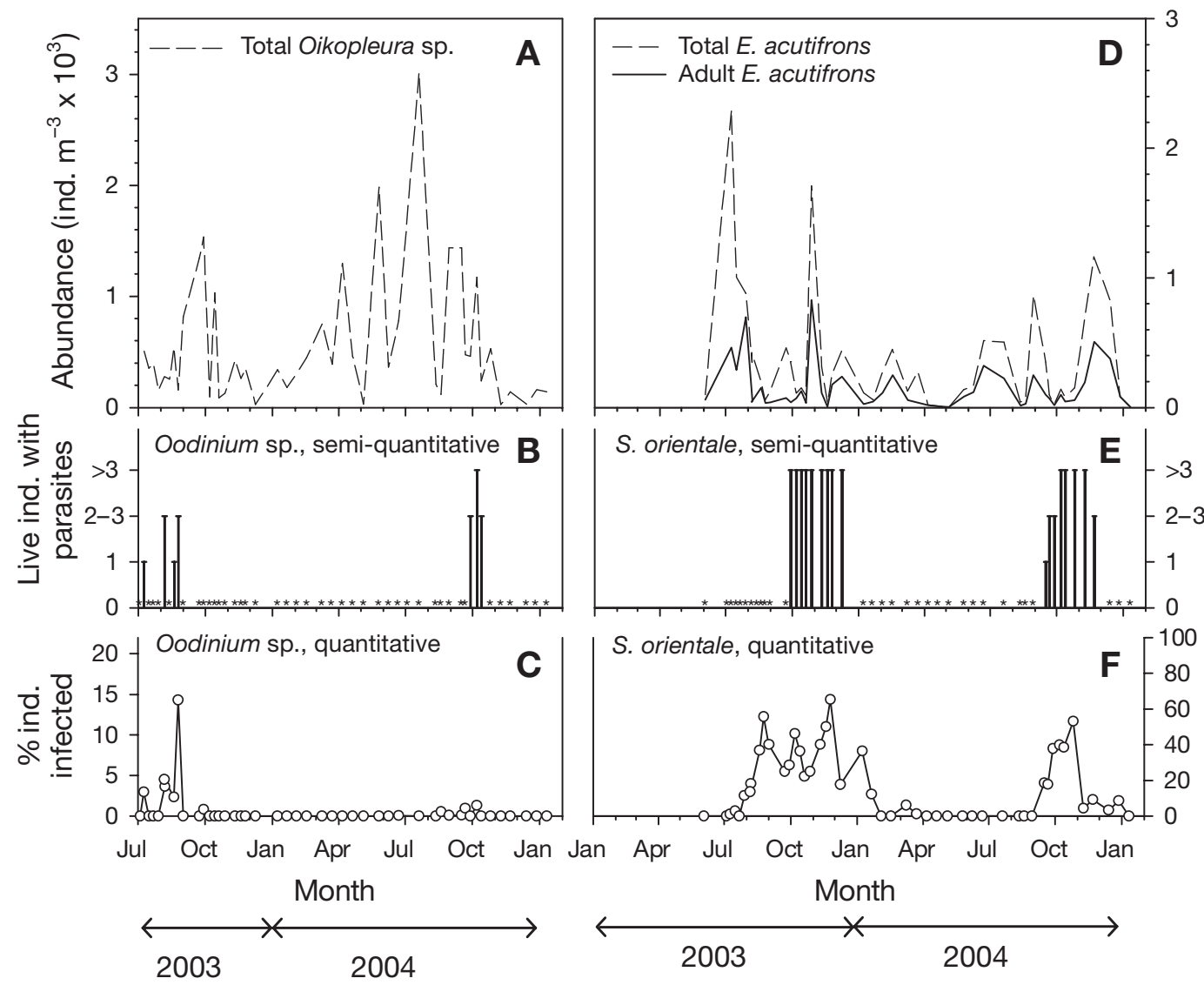

Fig. 6. (A) Oikopleura sp. total abundance. (B) Semi-quantitative prevalence of Oikopleura sp. infected with Oodinium sp. (bars). (C) Quantitative prevalence of Oodinium sp. on Oikopleura sp. (D) Euterpina acutifrons: total abundance and abundance of adults. (E) Semi-quantitative prevalence of E. acutifrons adults infested with the diatom Sceptronema orientale (bars). (F) Quantitative prevalence of $E$. acutifrons adults infested with $S$. orientale. $(\mathrm{B}, \mathrm{E}){ }^{*}$ : sample in which the parasite was not observed 


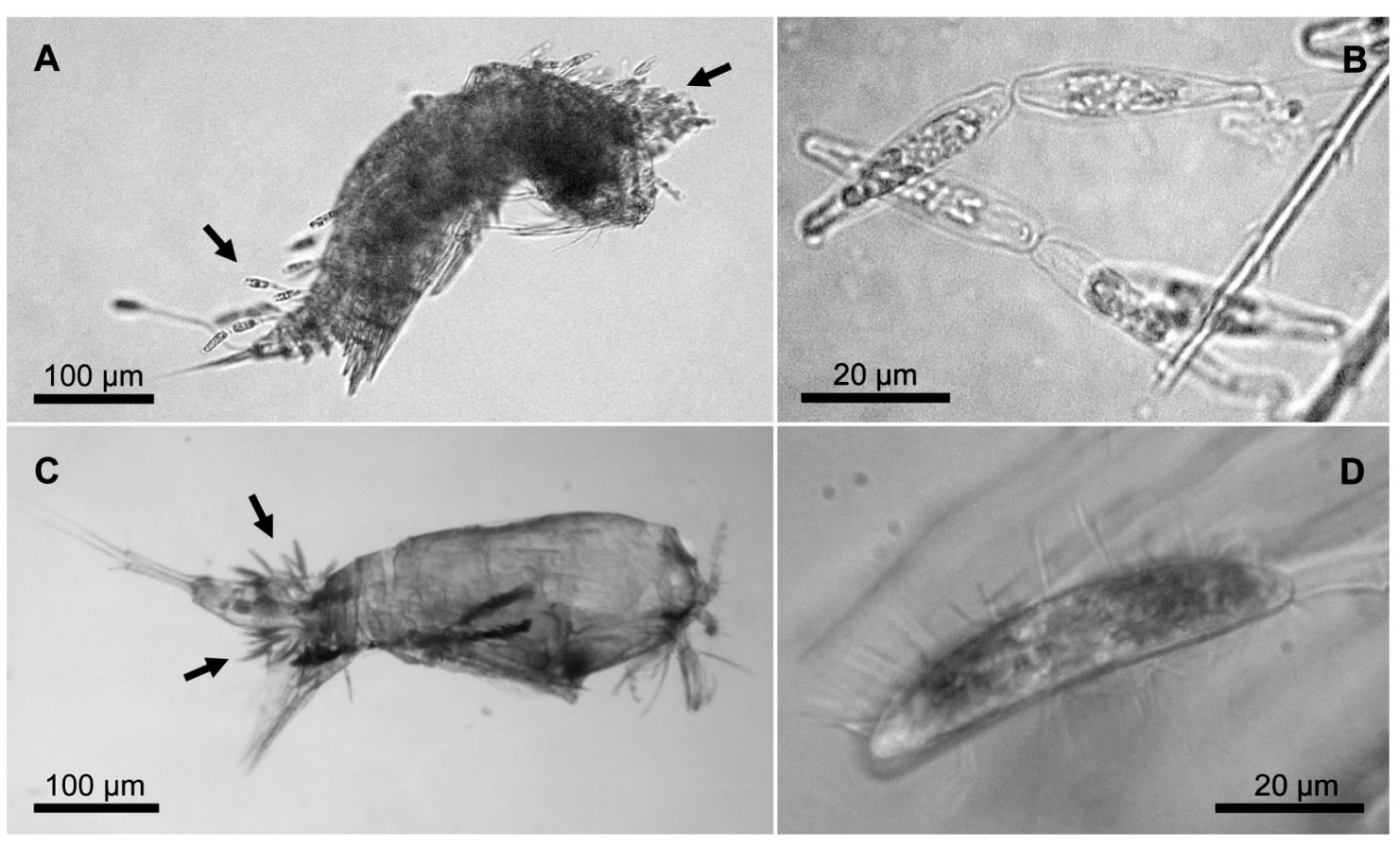

Fig. 7. (A) Sceptronema orientale (arrows) attached to Euterpina acutifrons. (B) S. orientale cells. (C) Pseudohimantidium pacificum (arrows) on Corycaeus sp. (D) P. pacificum cell

during the same periods. In 2003, S. orientale did not appear until mid-July and in 2004 it was absent between March and September. E. acutifrons was found in the plankton almost all year round (Fig. 6D) but only in relatively low numbers during spring 2004. Another epibiotic diatom, Pseudohimantidium pacificum, infested Corycaeus spp. (Fig. 7C,D). Like its hosts, the epibiont was observed infrequently and was never found from May to June (Table 1, Fig. 4G).

Cysts of an unknown ciliate were on several occasions found on the caudal rami of Corycaeus giesbrechti females. These ciliates were only found in late summer and autumn (Table 1). Total numbers of Corycaeus spp. in the samples were generally too low to determine prevalence of their parasites and epibionts.

\section{DISCUSSION}

\section{Host specificity}

A total of 12 parasites and epibionts were identified to species level. Of these, 9 were restricted to a single host species, 2 were found in 2 to 3 host species and 1 , Blastodinium contortum, was found in 4 different host species (Table 1). This suggests that some of these parasites are host specific. However, several of the seemingly host-specific parasites have previously been found to infect other hosts as well (Chatton 1920,
Sewell 1951), and it is possible that some parasites may be found in other host species if sampling is done more intensively. For example, B. oviforme in the present survey was found only in Oithona similis and in $O$. plumifera and not in O. nana, even though this potential host species was often present in the samples and has previously been reported as host for $B$. oviforme (Chatton 1920, Sewell 1951, Shields 1994). On the other hand, B. oviforme exclusively infected cyclopoid copepods; it was never found in potential calanoid hosts even though these were typically present in high abundances coexisting with infected Oithona spp. The same applies to Ellobiopsis sp.: in the present study, this parasite (which may comprise more than one species) was found on Temora stylifera and Calocalanus sp., but never infected any of the much more common and co-occurring species, such as Paracalanus parvus. In fact, Ellobiopsis sp. is known to infect more than a dozen copepod species, but has never been found on $P$. parvus (Shields 1994). An extreme case of host specificity is that of Sceptronema orientale. This epibiont has exclusively been found attached to Euterpina acutifrons, but with a wide geographical distribution encompassing Japanese waters (Takano 1983) as well as the eastern and the western parts of the Mediterranean Sea (Kimor et al. 1992, present study). Because of the sparse taxonomic information available on the genera Syndinium, Paradinium and Ellobiopsis, it is not presently possible to conclude whether these para- 
sites are specific to certain hosts. However, zoospores of Syndinium spp. originating from 2 different copepod species have been shown to be morphologically and genetically different (Skovgaard et al. 2005). In general, the data presented here on the existence of host specificity among parasites of marine zooplankton is in accordance with several earlier observations (Chatton 1920, Wickstead 1963, Kimmerer \& MacKinnon 1990). Hence, the adverse effect of parasitism is not equal for all copepod species. If parasitism can reduce zooplankton population sizes, it will also affect the relative abundance of host species and, thereby, the structure of the zooplankton community.

\section{Prevalence of parasites and epibionts}

In general, parasites were found at the time of year when their hosts were also most numerous, typically from late summer to early winter. In a study performed in adjacent coastal waters, principal occurrence in late summer and autumn was also noted for several parasite species (Chatton 1920). In the present study, Blastodinium spp. were found chiefly during autumn, but their occurrences were temporally slightly staggered. For example, B. mangini first appeared in July/August, whereas B. navicula appeared in August/September and B. contortum in November. Comparable seasonal differences could be seen in the abundances of the hosts of these parasites (Figs. $3 \& 4$ ). The occurrence of some parasites did not reflect the abundance of their hosts, e.g. Oodinium sp. had a limited period of occurrence, even though its host, Oikopleura sp., had several peaks of high abundances throughout most of the year. Syndinium turbo infected P. parvus throughout the year, but mainly in late summer and autumn. This limited seasonality in abundance concurs with the observations by Ianora et al. (1987, 1990). The only parasites that did not occur primarily in late summer/ autumn in the present survey were $B$. oviforme and Paradinium poucheti. Their hosts, Oithona spp., also had an earlier occurrence than most other copepod species (Fig. 4A). However, there was no statistically significant correlation between parasite prevalence and any of the parasite-host associations studied. This was conceivably due to a time lag between the peak in potential host density and maximum parasite prevalence, in combination with some threshold host density required for the successful reproduction of the parasite (May 1983). In addition, possible relationships between parasite prevalence and host abundance may be obscured by patchy distributions of both hosts and parasites.

In accordance with previous reports (Hiromi et al. 1985), the diatom Sceptronema orientale infested exclusively Euterpina acutifrons. From late summer to early winter, 20 to $65 \%$ of all E. acutifrons adults carried this diatom (Fig. 6F, Table 1). Juveniles were infested to a lesser extent, probably because they usually have shorter intermoult periods than adults and thereby loose their epibionts. Apart from the epibionts, infested hosts seemed healthy and infested females seemed to be fertile, since $30 \%$ of all eggcarrying females examined during the survey were infested with $S$. orientale. However, it cannot be excluded that large amounts of attached diatoms may have an adverse effect on their hosts, since freshwater zooplankton organisms bearing epibionts may be more conspicuous to predators and also undergo physiological stress (Willey et al. 1990, Allen et al. 1993). The pronounced seasonality in the occurrence of $S$. orientale suggests that this organism must either have a nonepibiotic life cycle stage, e.g. benthic resting cysts, or a morphologically different life cycle stage that has not yet been identified.

\section{Observed versus total parasite prevalence}

In this study, parasite prevalence was quantified by examining the morphology of fixed zooplankton. Many parasites, in particular endoparasites like the genera Blastodinium and Syndinium need to reach a considerable size before they are detectable during traditional microscopic studies. The total number of Blastodinium spp. found in the present study was considerable larger than in a previous study from a nearby location (Ianora et al. 1987), probably as a result of a better detection of these chlorophyllcontaining parasites in samples that have been stored in cold and darkness. Plasmodium-forming parasites like Paradinium spp. are not visible in a live host before external sporangia are formed. Furthermore, these sporangia seem to be lost during fixation. Paradinium spp. and to some extent Syndinium spp. are, therefore, only detectable in the final stages of that part of their life cycle that takes place in the zooplankton host. This is especially relevant for endoparasites; ectoparasites like Ellobiopsis spp., Oodinium spp. and epibiotic diatoms can be more accurately detected through microscopic examination. Hence, observed parasite prevalence is definitely an underestimate of total parasite prevalence, and more sensitive methods should be developed and applied to better assess total parasite prevalence. Detection of specific parasites may be facilitated by fluorescent staining (Kurtz et al. 2002), molecular probes (Le Roux et al. 1999) or, perhaps, systematic PCR-screening using species-specific primers targeting selected parasites (Audemard et al. 2002). 


\section{Do parasites regulate zooplankton populations?}

Mortality is one of the main factors shaping lifehistory traits and structure of planktonic communities (Verity \& Smetacek 1996) and also one of the most difficult parameters to quantify in nature. Although parasitism, by analogy with terrestrial and freshwaters systems, is always listed as a potential contributor to mortality (and productivity reduction) of zooplankton, its actual contribution is unknown. One can tentatively estimate the mortality and reduction in productivity of infected zooplankton based on our data and a few general assumptions. We here limit this analysis to the 3 cases for which we have most quantitative data: Blastodinium contortum in Paracalanus parvus, B. mangini in Oncaea cf. scottodicarloi, and Syndinium turbo in $P$. parvus. The latter parasite is lethal to its host, while Blastodinium spp. impair reproductive capability but only have a limited effect on the fitness of the individual host. We will focus only on adult female copepods because, according to our observations, the later and mature stages of these parasites are manifested essentially in adult females (although a limited number of infected juveniles was also observed). One basic assumption we make is that the host-parasite relationship is in steady state. We were only able to detect later stages of parasite infection, but this oversimplification (not applicable to any particular case) can be accepted if we take the average values of parasite prevalence into account. Fig. 3 data indicate that during their seasonal peaks $B$. contortum infected up to ca. $3 \%$ of $P$. parvus females, $B$. mangini infected 5 to $17 \%$ of $O$. cf. scottodicarloi females, and $S$. turbo infected up to $7 \%$ of $P$. parvus females. To convert these values into mortality ( $S$. turbo) and reproductive impairment (Blastodinium spp.) rates, estimations of the average duration time of the observed parasite stages are needed. In the case of $O$. cf. scottodicarloi infected with B. mangini, Skovgaard (2005) reported an average incubation time of $27 \mathrm{~h}$ before zoospores were released (turnover rate $0.9 \mathrm{~d}^{-1}$ ). Once visually detected in their host, $S$. turbo zoospores were released (resulting in the death of the host) within the first day of incubation, and usually within the first few hours (at $20^{\circ} \mathrm{C}, \mathrm{n}=30$, data not shown). This estimate agrees with the observation by Kimmerer \& MacKinnon (1990) that copepods infected with Syndinium sp. died after 17.5 to $37.6 \mathrm{~h}$ of incubation at 12 to $20^{\circ} \mathrm{C}$. We therefore tentatively assume that hosts died after 0.5 to $1 \mathrm{~d}$ of incubation (turnover rate 2 and $1 \mathrm{~d}^{-1}$, respectively) for $S$. turbo. Based on these assumptions, mortality rates $(m)$ can be calculated as $m$ $=\ln (1-p) / t$, where $p$ is the fraction of the host population that is infected and $t$ the duration of the parasite stage in days. Syndinium turbo would then be responsible, during their seasonal peak, for mortality rates of
0.08 to $0.15 \mathrm{~d}^{-1}$ for $P$. parvus females. In the case of Blastodinium spp., the impairment of reproductive rates would be 0.05 to $0.16 \mathrm{~d}^{-1}$ for $O$. scottodicarloi and up to $0.03 \mathrm{~d}^{-1}$ for $P$. parvus. This infertility of females due to parasitism results in a decrease in recruitment and can be compared to other sources of mortality at the population level. How well do these estimates compare to other sources of mortality in marine planktonic copepods? Local studies on mortality rates in the study site are lacking, except for that of Duró \& Saiz (2000), who estimated that chaetognaths (principal copepod predators) can account for a mortality rate of $0.04 \mathrm{~d}^{-1}$ in Centropages typicus adults. Hirst \& Kiørboe (2002) presented a global analysis of mortality rates in marine planktonic copepods, and concluded that mortality rates of copepod juveniles and adults are in the order of $0.1 \mathrm{~d}^{-1}$. The same study attributed the major part of mortality $(2 / 3$ to $3 / 4)$ to predation, with a range of variation of 2 orders of magnitude ( 0.01 to $1 \mathrm{~d}^{-1}$, their Figs. 6 \& 7). Our estimates of mortality and reproductive impairment are comparable to such above-mentioned values and indicate that parasitism can potentially contribute to mortality of adult copepods and affect recruitment of their populations. In conclusion, parasitic protists have the ability to regulate marine zooplankton populations as well as to influence community structure. Better quantitative estimates of these processes depend on an increased knowledge of parasite taxonomy, life cycles and biology.

Acknowledgements. A.S. was supported by the European Commission, Directorate General Research, through a Marie Curie Postdoctoral fellowship (Contract No. HPMF-CT2002-01931), and by the Carlsberg Foundation (04-0134/20). E.S. was funded through the Spanish MCYT projects ZOOTRANSFER (REN2001-1693) and MICROROL (CTM 2004-02575/MAR).

\section{LITERATURE CITED}

Albaina A, Irigoien X (2006) Fecundity limitation of Calanus helgolandicus, by the parasite Ellobiopsis sp. J Plankton Res 28:413-418

Allen YC, De Sasio BT, Ramcharan CW (1993) Individual and population level consequences of an algal epibiont on Daphnia. Limnol Oceanogr 38:592-601

Anderson RM, May RM (1978) Regulation and stability of host-parasite population interactions. J Anim Ecol 47: $219-247$

Audemard C, Le Roux F, Barnaud A, Collins CM and 6 others (2002) Needle in a haystack: involvement of the copepod Paracartia grani in the life cycle of the oyster pathogen Marteilia refringens. Parasitology 124:315-323

Bradbury PC (1996) Pathogenic ciliates In: Hausmann K, Bradbury PC (eds) Ciliates: cells as organisms. Gustav Fischer, Jena, p 463-477

Cachon J, Cachon M, Pyne CK (1968) Structure et ultrastructure de Paradinium poucheti Chatton 1910, et position systematique des Paradinides. Protistologica 4:303-311 
Cameron TWM (1956) Parasites and parasitism. Methuen, London

Carman KR, Dobbs FC (1997) Epibiotic microorganisms on copepods and other marine crustaceans. Microsc Res Technol 37:116-135

Caullery M (1910) Ellobiopsis chattoni, n. g., n. sp. parasite de Calanus helgolandicus Claus, appartenant probablement aux péridiniens. Bull Sci Fr Belg 44:201-214

Chatton É (1920) Les péridiniens parasites. Morphologie, reproduction, éthologie. Arch Zool Exp Gén 59:1-475, pl I-XVII

Chatton E, Soyer MO (1973) Le cycle évolutif du Paradinium poucheti Chatton, flagellé parasite plasmodial des copépodes. Les paradinides. Ann Sci Nat, Zool 15:27-60

Duró A, Saiz E (2000) Distribution and trophic ecology of chaetognaths in the western Mediterranean in relation to an inshore-offshore gradient. J Plankton Res 22: 339-361

Ebert D, Lipsitch M, Mangin KL (2000) The effect of parasites on host population density and extinction: experimental epidemiology with Daphnia and six microparasites. Am Nat 156:459-477

Fensome RA, Taylor FJR, Norris G, Sarjeant WAS, Wharton DI, Williams GL (1993) A classification of living and fossil dinoflagellates. Sheridan, Hanover

Fernandez-Leborans G, Tato-Porto ML (2000) A review of the species of protozoan epibionts on crustaceans. I. Peritich ciliates. Crustaceana 73:643-683

Gibson RA (1979) An ultrastructure study of Pseudohimantidium pacificum Hust. \& Krasske (Bacillariophyceae: Photoraphidaceae) with special reference to the labiate processes. Nova Hedwigia, Beih 64:147-156

Green J (1974) Parasites and epibionts of Cladocera. Trans Zool Soc Lond 32:417-515

Grimes BH, Bradbury PC (1992) The biology of Vampyrophrya pelagica (Chatton \& Lwoff, 1930), a histophagous apostome ciliate associated with marine calanoid copepods. J Protozool 39:65-79

Hiromi J, Kadota S, Takano H (1985) Diatom infestation of marine copepods (Review). Bull Tokai Reg Fish Res Lab $117: 37-45$

Hirst AG, Kiørboe T (2002) Mortality of marine planktonic copepods: global rates and patterns. Mar Ecol Prog Ser 230:195-209

Ho J, Perkins PS (1985) Symbionts of marine copepoda: an overview. Bull Mar Sci 37:586-598

Hovasse R (1951) Ellobiopsis fagei Hovasse, Ellobiopsidé parasite, en Méditerranée, de Clausocalanus arcuicornis Dana. Bull Inst Oceanogr 1016:1-12

Ianora A, Mazzocchi MG, Scotto di Carlo B (1987) Impact of parasitism and intersexuality on Mediterranean populations of Paracalanus parvus (Copepoda: Calanoida). Dis Aquat Org 3:29-36

Ianora A, Scotto di Carlo B, Mazzocchi MG, Mascellaro P (1990) Histomorphological changes in the reproductive

Editorial responsibility: Howard Browman (Associate Editorin-Chief), Storebø, Norway condition of parasitized marine planktonic copepods J Plankton Res 12:249-258

Kimmerer WJ, McKinnon AD (1990) High mortality in a copepod population caused by a parasitic dinoflagellate. Mar Biol 107:449-452

Kimor B, Gordon N, Neori A (1992) Symbiotic associations among the microplankton in oligotrophic marine environments, with special reference to the Gulf of Aqaba, Red Sea. J Plankton Res 14:1217-1231

Kurtz J, van der Veen, IT, Christen M (2002) Fluorescent vital labeling to track cestodes in a copepod intermediate host. Exp Parasitol 100:36-43

Le Roux F, Audemard C, Barnaud A, Berthe F (1999) DNAprobes as potential tools for the detection of Marteilia refringens. Mar Biotechnol 1:588-597

May RM (1983) Parasitic infections as regulators of animal populations. Am Sci 71:36-45

Ohtsuka S, Hora M, Suzaki T, Arikawa M, Omura G, Yamada K (2004) Morphology and host-specificity of the apostome ciliate Vampyrophrya pelagica infecting pelagic copepods in the Seto Inland Sea, Japan. Mar Ecol Prog Ser 282: 129-142

Sewell RBS (1951) The epibionts and parasites of the planktonic Copepoda of the Arabian Sea. Sci Rep John Murray Exped 9:255-394

Shields JD (1994) The parasitic dinoflagellates of marine crustaceans. Annu Rev Fish Dis 4:241-271

Silberman JD, Collins AG, Gershwin L, Johnson PJ, Roger AJ (2004) The ellobiopsid Thalasomyces is an alveolate. J Eukaryot Microbiol 51:246-252

Skovgaard A (2005) Infection with the dinoflagellate parasite Blastodinium spp. in two Mediterranean copepods. Aquat Microb Biol 38:93-101

Skovgaard A, Massana R, Balagué V, Saiz E (2005) Phylogenetic position of the copepod-infesting parasite Syndinium turbo (Dinoflagellata, Syndinea). Protist 156:413-423

Takano H (1983) New and rare diatoms from Japanese marine waters. XI. Three new species epizoic on copepods. Bull Tokai Reg Fish Res Lab 111:23-33

Théodoridès J (1989) Parasitology of marine zooplankton. Adv Mar Biol 25:117-177

Verity PG, Smetacek V (1996) Organism life cycles, predation, and the structure of marine pelagic ecosystems. Mar Ecol Prog Ser 130:277-293

Wickstead JH (1963) A new record of Ellobiopsis chattoni (flagellata incertae sedis) and its incidence in a population of Undinula vulgaris var. major (Crustacea Copepoda). Parasitology 53:293-296

Willey RL, Cantrell PA, Threlkeld ST (1990) Epibiotic euglenoid flagellates increase the susceptibility of some zooplankton to fish predation. Limnol Oceanogr 35:952-959

Xu Z, Burns CW (1991) Effects of the epizoic ciliate, Epistylis daphniae, on growth, reproduction and mortality of Boeckella triarticulata (Thomson) (Copepoda: Calanoida). Hydrobiologia 209:183-189

Submitted: November 8, 2005; Accepted: May 11, 2006 Proofs received from author(s): November 15, 2006 